\title{
Paternalist Liderlik Beklentisi: Y Kuşağı İşletme Öğrencileri Üzerine Bir Araştırma*
}

\author{
Ebru TOLAY ${ }^{1}$ \\ Özet
}

Bu çalışmanın temel amacı, Y Kuşağı bireylerin yöneticilerinden Paternalist Liderlik davranışları bekleyip beklemediklerinin tespit edilmesidir. Bu amaç doğrultusunda tasarlanan araștırma ile İzmir ilindeki bir devlet üniversitesinin İşletme Bölümünde öğrenim gören 291 Y Kuşağı öğrencinin, gelecekte yöneticilerden bekledikleri ideal liderlik davranışları ölçülmeye çalışılmıştır. Araştırmada Aycan (2006) tarafından geliştirilen Paternalist Liderlik Anketi - PLA kullanılmıștır. Faktör analizi sonucunda, orijinal ölçekte olduğu gibi beş faktörlü yapı tespit edilmekle birlikte Sadakat Beklentisi yerine Koruyucu Ebeveyn Davranışları olarak adlandırılan yeni ve farklı bir boyutun ortaya çıktığı görülmüștür. Tek örneklem t testi sonucunda, katılımcıların gelecekteki yöneticilerinden bekledikleri Koruyucu Ebeveyn Davranışı, Statü Hiyerarşisi ve Otorite, İş Yerinde Aile Ortamı Yaratma ve Bireyselleştirilmiş İlş̧ki düzeylerinin, varsayıldığı üzere, ortalamadan farklı ve yüksek olduğu saptanmıştır. İş Dışı Konularla İlgilenme düzeyinde ise anlamlı bir farklılık bulunamamıştır.

Anahtar kelimeler: Y Kuşağl, Paternalizm, Paternalist Liderlik

Jel Kodu: M12, M14

\section{Paternalistic Leadership Expectations: A Research on Generation Y Business Students}

\begin{abstract}
Main purpose of this study is to determine whether generation Y individuals expect Paternalistic Leadership behaviors from their managers. In this context, ideal leadership behaviors from future managers expected by 291 generation $Y$ Business students of a state University in Izmir were aimed to measure. Paternalistic Leadership Questionnaire - PLQ developed by Aycan (2006) was used in the study. Although five-factor structure as original scale was determined as a result of factor analysis, a different and a new dimension referred as Protective Parent Behaviors instead of Loyalty Expectation has emerged. As a result of One Sample T Test, levels of Protective Parent Behaviors, Status Hierarchy and Authority, Creating Family Atmosphere at Work and Individualized Relationships expected by participants from future managers are different and higher than mean value was determined, as supposed. No significant difference for Involvement in Employees' Non-Work Lives level was founded.
\end{abstract}

Keywords: Generation Y, Paternalism, Paternalistic Leadership

Jel Codes: M12, M14

\section{GíRIŞ}

Türkiye'de, iş görenlerin yöneticilerinden nasıl bir liderlik tarzı bekledikleri, son yıllarda daha kapsamlı bir şekilde araştırılmaya başlanmıştır. Türk yönetim tarihi ve kültürü incelendiğinde, "aileye dayalı örgütlenme", "merkeziyetçilik" ve "hiyerarşiye saygı gösterme" gibi değerlerin her zaman ön planda tutulduğu dikkat çekmektedir. Geçmişi
Anadolu medeniyetlerine kadar uzanan bu kültürel özelliklerin doğal bir sonucu olarak günümüz Türkiye'sinde iş görenler, yöneticilerinden kendilerine adeta bir "baba" gibi davranmalarını, onları korumalarını, haklarını gözetmelerini, kurum içinde aile bağlarına benzer yakın ilişkilerin kurulmasını beklemekte; bunun karşılığında da liderlerine bağlılıklarını sunmakta ve gönüllü olarak

* Bu makalede bilimsel araştırma ve yayın etiği ilkelerine uyulmuştur. / In this article, the principles of scientific research and publication ethics were followed.

ATIF ÖNERISİ (APA): Tolay, E. (2020). Paternalist Liderlik Beklentisi: Y Kuşağı İşletme Öğrencileri Üzerine Bir Araştırma. İzmir İktisat Dergisi. 35(1). 123-139. Doi: 10.24988/ije.202035110

${ }^{1}$ Dr. Öğr. Üyesi, Dokuz Eylül Üniversitesi, İktisadi ve İdari Bilimler Fakültesi, İşletme Bölümü, Yönetim ve Organizasyon ABD, İzmir EMAIL: ebru.tolay@deu.edu.tr ORCID: 0000-0001-5363-8823 
onlara itaat etmektedirler. Ast-üst arasındaki bu paternalist ilișki, Kuzey Amerika ve Batı Avrupa kültürel ortamında yaygın olmayan ve benimsenmeyen bir ilişki tarzıdır. Geleneksel doğu kültürlerinde ise yetki sahibi kişilerden, erkekse bir baba veya ağabey; kadınsa bir anne veya abla gibi (maternalizm) davranmaları beklenir. Paternalist bir yöneticiye, yalnızca işle ilgili değil; aileyle ilgili konularda da danıșlır. Batı toplumlarında ise bu tür girișimler, bireyin özgürlügünü kısıtlayıcı ve hayatına müdahale edici hareketler olarak düşünülür. Bu özellikleri ile paternalizm, kültürleri birbirinden ayıran en belirgin özelliklerden biridir ve özellikle iş hayatını pek çok yönden etkilemektedir.

Paternalist kültür özellikleriyle uyumlu olduğu kabul edilen Türkiye'de, Y kuşağına üye bireylerin, yöneticilerinden paternalist liderlik davranışları bekleyip beklemedikleri, bu çalışmanın temel sorusunu oluşturmaktadır. Çalışmanın temel varsayımı ise iyi eğitimli, kişisel destek isteyen, dişsal geribildirim bekleyen, takım oyuncusu, aileye düşkün, iş ve yaşam dengesi arayan ve özellikle teknolojideki hızlı değişime mükemmel uyum sağlamaları ile dikkat çeken Türkiye'deki Y Kuşağının, yöneticilerinden paternalist liderlik davranışları beklemeyi sürdürdükleri yönündedir. $\mathrm{Bu}$ varsayımın kaynağı hem Türk kültürünün kökleşmiş etkilerine hem de Paternalist Liderin Y Kuşağına özgü birtakım beklentileri karşılama olasılığının yüksek olmasına dayandırılabilir. Örneğin, Y Kuşağı bireylerin, ailelerinden gördükleri özel ve yoğun ilgiyi, iş yaşamına başladıklarında yöneticilerinden de bekledikleri bilinmektedir. $\mathrm{Bu}$ noktada babacan, tatlı-sert, iş yerinde aile ortamı sağlayan, astlarının gerek işle ilgili gerekse iş dışı yaşamlarıyla ilgili her tür soruna eğilen paternalist bir liderlik yaklaşımının faydalı olacağı düşünülmektedir.

Günümüzde, iş yaşamında farklı yönetim kademelerinde bulunan birçok yönetici, Y kuşağına liderlik etme konusunda sorunlar yaşadıklarını dile getirmektedir. İş ve yönetim dergileri, Y kuşağının ve hatta yakın gelecekte aktif olarak işgücüne katılması beklenen $\mathrm{Z}$ kuşağının nasıl yönetileceğine; beklentilerinin nasıl karşılanabileceğine geniş yer ayırmaktadır. Uluslararası çapta birçok araştırma ve danışmanlık şirketi (Deloitte, PricewaterhouseCoopers, Place to Work, BAREM vb.), $Y$ Kuşağını tanımak ve örgütlerinden beklentilerini tespit etmek üzere düzenli olarak Kuşak Araştırmaları gerçekleştirmektedir. Bu bağlamda, teoride Y Kuşağının özelliklerine ve beklentilerine ilişkin hatırı sayılır bir bilgi birikimi oluştuğu söylenebilir. Bununla birlikte, pratikte, bu bilgiler yöneticiler tarafından yorumlanırken ve kullanılırken kültürlerarası farklılıkların ve ulusal kültürün özelliklerinin göz ardı edilmemesi gerekir. Örneğin, Yüksekbilgili (2013: 353), İstanbul'da 603 kişi ile yaptığ araştırmaya dayanarak, uluslararası literatürde Y Kuşağına özgü olduğu ileri sürülen temel özelliklerin Türk Y Kuşağı için tamamıla geçerli olamayacağ ulaşmıştır.

Bayramoğlu (2018: 27) ise günümüzde kuşak değişiminden ziyade teknolojinin değişiminden bahsedilebileceğini ileri sürerek tartışmayı bir adım daha ileri taşımıştır: "Hızla değișen teknoloji, iş yapma şekillerini ve çalışanların kurumlarından beklentilerini farklılaştırmaktadır. Ancak burada sorulması gereken sorular şunlardır: "Peki sadece Y Kuşağının mı beklentileri farklılaşmıştır? Teknolojiyi kullanmak sadece Y Kuşağı ile mi özdeşleștirilebilir? Bu sorulara verilecek en klasik cevaplar bile tüm kuşakların yaşam tarzında bir değişimin söz konusu olduğunu ortaya koyacaktır."

Literatürdeki bu tür sorulara sağduyulu ve emik bir yaklaşımla yanıt aramanın daha sağlıklı olacağı düşünülmektedir. Zira bu çalışmada, ulusal kültürdeki değişimlerin, günümüzde $Y$ ve $Z$ Kuşaklarını önceki kuşaklardan farklılaştıran teknolojik değişimleri de kapsayan daha geniş bir olgu olduğu ve daha yavaş bir değişim eğilimi gösterdiği varsayılmaktadır. Bu açıdan, Türk 
kültürü ile uyumlu olan paternalist liderliğin, Y kuşağının beklentilerini karşılamada başarılı olabileceği düşünülmektedir.

Bu çerçeve içerisinde, bir ön araştırma olarak tasarlanan bu çalışmada, İzmir'deki bir devlet üniversitesinde öğrenim gören İșletme Bölümü öğrencilerinin ideal bir liderden bekledikleri davranışlar ölçülmeye çalışılmıştır. Böylece ülkenin farklı şehirlerinden gelen Y kuşağı gençlerin liderlik beklentilerini paternalizm boyutu çerçevesinde değerlendirmek hedeflenmiştir. Yapılan literatür taramasında, paternalist liderlik ve Y Kuşağı ile ilgili ayrı ayrı çok sayıda çalışma bulunmakla birlikte, doğrudan Y Kuşağının paternalist liderlik beklentilerini ölçen bir çalışmaya rastlanmamıştır. $\mathrm{Bu}$ bakımdan, böyle bir çalışmanın, paternalizm, liderlik ve kuşaklar ile ilgili literatürlere katkı sağlaması beklenmektedir. Buna ilave olarak, iş dünyasındaki yöneticilere $Y$ Kuşağı ile yaşadıkları sorunların çözülmesinde ve ilişkilerin daha bilinçli bir şekilde yönetilmesinde fikir vermesi umulmaktadır.

\section{KURAMSAL ÇERÇEVE}

$\mathrm{Bu}$ başlık altında, önce Paternalist Liderlik olgusu tanıtılacak, daha sonra Y Kuşağının temel özellikleri, bu kuşağın üyelerinin örgütlerinden ve yöneticilerinden beklentileri ele alınacaktır. Son olarak, Türkiye'de Y Kuşağı ve Paternalist Liderlik ilişkisi incelenecektir.

\subsection{Paternalist Liderlik Olgusu}

Çin, Japonya, Kore ve Hindistan gibi Pasifik Asya kültürlerinin önemli bir özelliği olan paternalizmin temel prensipleri, işverenin ya da yöneticinin otoritesi ve yol göstericiliği karşıllığında, çalışanların ona bağlılık ve saygı göstermesi gerektiğini öğütleyen Konfüçyüs öğretilerine dayandırılmaktadır (Aycan, 2001: 12-13). Paternalist liderlik, ataerkil düşünceye dayanan, aile içindeki hiyerarşiyi anlatan bir tutum ya da davranış şeklidir. Aile içerisinde 'baba' ile sembolleșen bu kavramın temelinde, kendi isteklerini ve menfaatlerini göz ardı edecek şekilde ailenin diğer fertlerinin yararı doğrultusunda kararlar almayı gerektiren fedakârlık, sevgi ve korumacl anlayıș yatmaktadır. Bu liderlik yaklaşımında, liderin işyerinde bir aile atmosferi yaratması, izleyenlerine baba gibi yaklaşması, takipçilerinin iş hayatı dışındaki özel hayatları ile ilgilenmesi için her türlü çabayı sarf etmesi gibi konular bulunmaktadır (Erkuş vd., 2010: 594).

Paternalist toplumlarda ast ile üst arasındaki ilişki, ebeveyn ile evlat arasındaki ilişkiye benzemektedir. $\mathrm{Bu}$ ilişkide üstün görevi astı korumak, yönlendirmek, yol göstermek ve onun iyiliğine olacağına inandığı kararları onun adına vermektir. Bunun karşıllı̆ında da asttan beklenen, üstüne kayıtsız șartsız itaat etmesi ve bağlllık göstermesidir (Aycan ve Kanungo, 2000: 31). Bu bağlamda paternalist lider, takipçileri tarafından otoriter, sorumluluk alan, doğrudan karar verici ve yardımsever görüntüsü baskın özellikler gösteren, aynı zamanda tatlı-sert babacan bir lider profili çizmektedir (Şendoğdu ve Erdirençelebi, 2014: 253).

Paternalizm geleneksel Doğu toplumlarında önemli ve istenen bir kültürel-yönetsel özellik olmasına karşılık, Batı toplumlarında son derece olumsuz anlamlar içermektedir. $\mathrm{Bu}$ saptamayı yapan Aycan'a göre (2001: 13), paternalizmin hâkim olduğu ast-üst ilişskilerinde liderler-yöneticiler, çalışanlara tıpkı bir babanın evlatlarına davrandığı gibi davranır. Dolayısıyla, liderler çalışanlarının hayatlarının her yönüyle (sosyal, ailevi, mesleki vb.) derinlemesine ilgilenirler. İş ve sosyal hayatın birbirinden azami ölçüde ayrıştırılmaya çalışıldığı ve iş ilişkilerinde profesyonelliğin hâkim olduğu toplumlarda ise yöneticinin çalışanlara bu denli yakınlık göstermesi ve hayatlarının her yönüyle ilgilenmesi rahatsızlık yaratmakta ve mahremiyetlerine müdahale şeklinde algılanmaktadır.

Paternalist kültür özelliklerinden biri olan, gücü-yetkiyi elinde bulunduran kişinin (devlet, lider, yönetici, ebeveyn); vatandaş, çalışan, takipçiler ya da çocuk için neyin iyi olacağına kendisinin karar vermesi durumu, 
bu tür toplumlarda sık karşılaşılan bir olgudur (Erben, 2004: 348). Çalışanlar da gönüllü olarak bunu kabul ederler. Bireyci ve eşitlikçi Batı toplumları ise kişi adına, onunla ilgili kararlar alınabilmesini kabul edilemez bulmakta; astın buna nasıl razı olduğunu ise anlayamamaktadır. Bu nedenle bireyci Batı toplumlarında paternalizm, özerklik ve seçim özgürlügü hakkını kısıtlayan bir uygulama olarak görülmektedir. Aycan (2006: 449), paternalist lider davranışlarını aşağıdaki şekilde özetlemektedir:

- İşyerinde aile ortamı yaratmak: Astlara bir baba gibi davranmak; profesyonel yaşamları kadar özel hayatlarıyla ilgili de babacan tarzlarda nasihat vermek.

Astlarla yakın ve kişisel ilişkiler kurmak: Tüm astlarla, kişisel olarak yakın ilişkiler kurmak; her bir astı birey olarak (kişisel sorunlarını, aile yaşamını vb.) bilmek; onların refahı ile samimi bir biçimde ilgilenmek; astların mesleki ve kişisel yaşamlarına yakından ilgi göstermek.

- İş dışı alanlara da dahil olmak: Hem astların hem de onların en yakın aile üyelerinin önemli günlerinde (örneğin dügün ve cenaze törenleri, kutlamalar vb.), ihtiyaç duyuyorlarsa onlara yardım ve destek de sağlayarak (finansal destek gibi) hazır bulunmak; bir ast ile eşi arasında evliliklerine ilişkin sorunlar olduğunda arabuluculuk yapmak.

- Sadakat beklemek: Astlardan bağlılık ve sadakat beklemek; kurumda acil bir durum olduğunda, bu onların özel yaşamlarından fedakârlık yapmalarını gerektirse bile, derhal hazır bulunmalarını beklemek.

- Otoriteyi/statüyü korumak: Statü farklılıklarına önem vermek ve astların da bu yönde davranmalarını beklemek; astlar ve onların kariyerleri için neyin iyi olduğunu bildiğine inanmak; herhangi birinin, kendisinin otoritesinden kuşku duymamasını istemek.

Aycan ve Kanungo'nun (2000: 41) 10 ülkeden 2003 yönetici ve çalışan ile gerçekleştirdikleri araştırmada, paternalizmin en çok gözlendiği ülkelerin Hindistan, Pakistan, Çin ve Türkiye olduğu saptanmıştır. Bulgular, araştırmaya katılan 10 ülke arasında, Türkiye'nin paternalizm ve topluluğa bağlılık boyutlarında ikinci olduğunu göstermektedir. Aynı araştırma, Türkiye'de, çalışanların proaktif olmadıklarına ve işlerini bağımsız, inisiyatif alarak yapamadıklarına yönelik inancın da kurumlarda yerleșmiș olduğunu göstermiștir (Aycan ve Kanungo, 2000: 46). Aycan'a göre (2001:26), çalışanların arkalarını baba veya ağabey yerine koydukları yöneticilerine yaslamaları ve onun yol göstericiliğine ihtiyaç duymaları, proaktif olmayı engelleyici bir faktör olarak ortaya çıkmaktadır. Böyle bir ilişkide inisiyatif almayı ve bağımsız hareket etmeyi engelleyen bir diğer etken de yöneticiye duyulan saygı ve bağlılıktır.

Aycan ve Fikret-Paşa (2000) tarafından Türkiye'de tercih edilen liderlik tarzını ortaya çıkarmaya yönelik gerçekleştirilen bir başka araştırmanın sonucuna göre, en çok tercih edilen liderlik tarzlarının sırasıyla karizmatik, katılımcl, paternalist ve bürokratik liderlik olduğu saptanmıştır (Aktaran: Aycan, 2001: 27-28). Benzer şekilde, Türkiye'nin çeşitli coğrafi alanlarında 4824 kişi üzerinde yapılan kapsamlı bir diğer araştırmanın bulgularına göre, en baskın ve yaygın yönetici/lider tipolojisi sırasıyla otoriter (\%53), paternalist $(\% 25)$, danışman $(\% 13,6)$ ve demokratik $(\% 8,5)$ yöneticilerdir. En çok tercih edilen liderlik tarzları ise yine sırasıyla danışman $(\% 35,2)$, paternalist $(\% 28,9)$, demokratik $(\% 25,6)$ ve otoriterdir $(\% 10,3)$ (Kabasakal ve Bodur,2008:851).

Schroeder'in (2011: 36) Türkiye'de aile işletmeleri ve çokuluslu şirketler üzerinde yaptığı araştırmada da anlamlı sonuçlar elde edilmiştir. Çalışanlar tarafından rapor edilen paternalist lider davranışları ve örgütsel toplulukçuluk düzeyleri, aile işletmelerinde, 
çokuluslu işletmelere kıyasla, anlamlı șekilde yüksek çıkmıştır. Benzer biçimde, paternalist liderliğin, 'iş yerinde aile atmosferi', 'bireyselleştirilmiş ilişskiler', 'iş dışı yaşama dahil olma', 'sadakat beklentisi' ve 'statü/otorite' alt boyutlarının tümünde, aile işletmelerinde çalışanların puanlarının, çok uluslu işletmelerde çalışanlardan daha yüksek olduğu görülmüştür. $\mathrm{Bu}$ bulgular, aile bağlarının daha güçlü hissedildiği aile işletmelerinde, paternalizmin daha fazla görüldüğü veya algılandığı șeklinde yorumlanabilir.

$\mathrm{Bu}$ çalışmalara ilave olarak, Türkiye'de paternalist lider davranışlarının örgütsel özdeşleşme (Erkuş vd., 2010); örgütsel toplulukçuluk (Schroeder, 2011); lider-üye etkileşimi (Pellegrini, 2006; Schroeder, 2011); iş doyumu (Schroeder, 2011; Cerit, 2012); yöneticiden memnuniyet (Cerit, 2012); işyaşam gelişimi (Erben ve Ötken, 2014) ve örgütsel vatandaşlık davranışı (Schroeder, 2011; Şendoğdu ve Erdirençelebi, 2014; Mete ve Serin, 2015) değişkenleri ile anlamlı ve pozitif ilişkili olduğunu destekleyen çeşitli araştırmalara rastlanmaktadır. Ayrıca, Mete ve Serin (2015: 154) tarafindan yapılan araştırmada paternalist liderlik davranışına ilişkin olarak öğretmenlerin algıları pozitif yönde arttığında, örgütsel sinizm tutumlarının azaldığı da saptanmıştır. $\mathrm{Bu}$ sonuçlara dayanarak Türkiye'de paternalist liderlik davranışlarının olumlu iş tutumlarını artıran ve olumsuz tutumları da azaltan önemli bir faktör olduğu söylenebilir.

\subsection{Y Kuşağının Temel Özellikleri}

Kuşak teorisi (kuşakların sosyolojisi), ilk kez 1923 yllında Karl Mannheim tarafından "Problem of Generations" isimli çalışmada ileri sürülmüștür. Mannheim kuşak kavramını, "belirli bir zaman diliminde önemli tarihsel olayları yaşamış belirli bir yaștaki insanların oluşturduğu bir grup" olarak tanımlamıștır (Bayramoğlu, 2018: 15-16). Her kuşağın kendine has tipik özellikleri ve değer yargıları olmasından dolayı, bireyler doğdukları kuşakların davranışlarına benzer tutumlar sergilerken diğer kuşaklardan farklı tutumlara sahip olabilmektedirler (Göktaş ve Çarıkçı, 2016: 856).

Kuşaklar literatürde, Sessiz Kuşak (19251945), Bebek Patlaması Kuşağı (1946-1964), X Kuşağı (1965-1979), Y Kuşağı (1980-1999) ve $Z$ Kuşağı (2000 ve sonrasında doğanlar) biçiminde sınıflandırılmaktadır (Ekiz, 2017: 5; Özkan, 2017: 86). Bu ayrımın belirlenmesi, kuşaklar arasındaki farklılıkların ortaya konabilmesi açısından önem taşımaktadır.

Türkiye İstatistik Kurumu'nun (TÜIK) 2016 yılı İşgücü İstatistiklerine göre Türkiye'de yaşayan 79,8 milyon kişinin 26 milyonunun $Y$ kuşağı üyesi olduğu ve çalışan nüfus içindeki toplamının ise 15 milyonu geçtiği belirtilmektedir (Ekiz, 2017: 12; Özkan, 2017: 107). Diğer taraftan günümüzde iş yaşamındaki çalışan profilini Bebek Patlaması, $\mathrm{X}$ ve $\mathrm{Y}$ Kuşakları oluşturmaktadır. $\mathrm{Bu}$ kişiler motivasyon, iş yapma şekli, teknolojiye olan yakınlık ve iş konularında farklı beklentilere sahip olup aynı iş ortamında birlikte çalışıyor olmanın sıkıntılarını yaşamaktadırlar (Erdem Okumuş, 2016: 13). Bu bakımdan farklı toplumsal olaylar yaşamış, farklı sıkıntılar ve yükümlülüklerle karşıllaşmış kuşakların beklentilerini anlamak, iş yaşamı açısından oldukça önemlidir. Özellikle mevcut işgücü piyasasında en büyük payı oluşturan $\mathrm{Y}$ Kuşağının özelliklerini ve beklentilerini iyi anlamaya yönelik çabalar, birçok faydayı beraberinde getirecektir (Özkan, 2017: 109).

Y kuşağı üyeleri, doğru yönetildiklerinde ve yönlendirildiklerinde yeteneklerinden son derece yüksek düzeyde faydalanılabilen, verimlilikleri artırılabilen ve aynı anda birden fazla işi yapabilen bireylerdir. (Erdem Okumuş, 2016: 9). Gerçekten de Y Kuşağl, iş yaşamında yer almaya başladığı andan itibaren bilgi ve iletişim teknolojilerinin kurallarını yeniden yazmış; kurum kültürlerinde birçok değişikliğe yol açmışlardır. Literatürde, $Y$ Kuşağının yeni nesil bir işgücü olduğu ve bunun, dünyanın her yerinde hissedildiği, işverenlerin ve 
yöneticilerin de mevcut iş ortamlarını ve uygulamalarını bu kuşağa göre adapte etmeleri gerektiği belirtilmektedir (Özkan, 2017: 126).

Y Kuşağının temel özelliklerinin sıralandığı çok sayıda çalışmada, özellikle "aile bağları", "iş-yaşam dengesi arayışları", "teknoloji ile ilişkileri", "kariyerleri ile ilgili tercihleri ve beklentileri" ve "eğitim ve gelişim faaliyetlerine yaklaşımları" gibi konuların öne çıktığı dikkat çekmektedir. Aşağıda bu konulara kısaca yer verilmesinin, Y Kuşağını anlamak açısından önemli olduğu düşünülmektedir.

Aile Bağları: Kuşaklarla ilgili pek çok çalıșmada Y kuşağı ile ilgili dile getirilen önemli bir husus aile bağlarıdır. Bu kuşağın üyeleri ile ebeveynlerinin, önceki kuşaklara kıyasla, birbirlerine çok daha bağlı oldukları bilinmektedir. Hatta, çocukları ile ilgili bir sorun olur olmaz hemen yanlarında olduklarından, bu kuşağın ebeveynleri için "helikopter aileler" ifadesi kullanılmaktadır (Çevik Tekin ve Akgemci, 2016: 47). Bu ailelerin aşırı müdahil ve korumacı olmaları, sürekli kendisi ile ilgilenilmesi konusunda yüksek beklentiye sahip bir kuşağın ortaya çıkmasına neden olmuştur. Y Kuşağı üyeleri, aileleri ile yakın ilişki içerisindedirler ve bundan mutlu olduklarını belirtmektedirler (Bayramoğlu, 2018: 17-18).

İş-Yaşam Dengesi Arayışları: Y Kuşağ üyelerinin en belirgin özelliklerinden biri, işi, hayatlarının en önemli parçası olarak görmemeleri; hayatlarının merkezine yerleştirmemeleridir. İş, çoğu zaman, yaşamak için gerekli bir şeyden daha fazlası değildir. Dolayısıyla iş yerinin sunduğu tatil olanaklarına çok önem verirler; yavaş çalışabilecekleri ve sıkı denetim altında olmayacakları işleri tercih ederler (Özkan, 2017: 111) ve genellikle daha iyi bir iş-yaşam dengesi için örgütlerinden ve yöneticilerinden esnek saatler ve programlar talep ederler (Wiedmer, 2015: 57).

Teknoloji ile İlişkileri: Y kuşağı, dünyadaki olaylar hakkında kesintisiz bilgiye bilgisayarlar, Internet, mobil telefonlar vb. teknolojiler ile bağlanarak ulaşılabilen bir çağda yetişmişlerdir (Wiedmer, 2015: 54). Dijital olanaklar ve küreselleşme çerçevesinde, televizyondan ziyade interneti geliştiren bir kuşak olduğundan, 'iletişim', 'kișisel özgürlük', 'hak' gibi kavramlar bu kuşağın en önemli değerlerini olușturmaktadır (Göktaș, 2016: 35). Teknoloji becerilerini, yaratıcı bir şekilde, sahip oldukları görevleri ilerletmek ve sonuçlar elde etmek için kullanmaktadırlar (Özkan, 2017: 100). Diğer yandan, kendilerinden bir şey istendiğinde ve bu şey akıllarına yatmadığında internetten kontrol ederek öyle karar verme yönleriyle de şüpheci bir yaklaşım sergilerler. Y Kuşağı üyeleri, dünyayla ve insanlarla doğal bir etkileşim içindedirler ve en başta gelen etkileşim araçları internettir. Teknolojiye bağımlılıkları ve sürekli teknolojiye bağlı kalma eğilimleri yüksektir (Erdem Okumuş, 2016: 10-11).

Kariyer Tercihleri: Çalışacakları örgütü seçerken şirketin örgütsel kimliği, iklimi, etik değerleri, uluslararası yapısı, ișveren markası konumlaması, kariyer ve eğitim olanakları, esnek çalışma gibi yaklaşımlarını değerlendirirler. Mezun olduktan sonra kısa bir süre içerisinde iș bulabileceklerini düșünmektedirler. İş yaşamına adım attıktan kısa bir süre sonra ise kendilerini yönetici olarak görmektedirler (Kuru, 2014: 3-4). Nitekim Y Kuşağı üyeleri, çalışma yaşamına girer girmez terfi olanaklarını aramaya başlarlar (Özkan, 2017: 113).

Y Kuşağl, işlerinde ve sosyal yaşamlarında mutluluğun peşinde olduklarından, "tek iș, tek kariyer" zihniyeti onlar için geçerli değildir. Çoklu iş fırsatlarını izleyerek iş ve özel yaşamı bütünleştirirler. (Wiedmer, 2015: 55). Diğer taraftan Y Kuşağı üyeleri, çalıştığı iş, yaşamdan beklentilerini karşılamıyorsa yeni iş olanakları ararlar ve bunu bencillik olarak değil gerçekçilik olarak görürler (Yüksekbilgili, 2013: 346).

$\mathrm{Bu}$ bilgilerden de yararlanarak Y Kuşağının temel özellikleri Tablo 1'de sıralanmıștır: 
Tablo 1: Y Kuşağının Temel Özellikleri ILETIŞIM VE TEKNOLOJi

Teknoloji tutkunudurlar.

Açık ve net iletişim kurmayı tercih ederler.

Kapalı, imaya dayalı iletişimi benimsemezler.

En önemli etkileşim araçları internettir.

Çift yönlü iletişimi önemserler.

E-mail ve kısa mesaj ile iletişim kurmayı, yüz yüze iletişime tercih ederler.

Kendilerini ifade etmekte yetkindirler

\section{KișiLÍK ÖZELLIKLERI}

Bireyci, 'Ben' merkezci, Başarı odaklı

Bağımsızlıklarına düşkün; sınırlandırıldıklarında tepkisel

Hırslı, Sabırsız, Talepkâr

Girişimci, Yenilikçi

Şüpheci, Araştırmacı, Sorgulayıcı, Farkındalığı yüksek

İtirazcı; tartışmayı seven

Özgüveni yüksek, Eleștiriye tahammülleri çok düşük

İyimser, Umutlu

Aile odaklı, Takım odakl, Sosyal

Zor beğenen, Kolay tatmin olmayan

\section{ÖRGÜTSEL DAVRANIŞLARI}

İş konusunda seçici

Yüksek otoriteden rahatsız

Hızlı (Teknoloji sayesinde hızlı düşünme, hızlı hareket etme, hızlı tüketme), Pratik

Örgüte karşı sadakat duyguları düşük

Kısa sürede sık iş değiştirebilen

Farklı alanlarda sorumluluk almaya istekli

Yoğun çalışmaya istekli

Bir araya getirici, kucaklayıcı liderlik anlayışı

ÖRGÜTTEN VE YÖNETICILERINDEN BEKLENTILERİ

Yüksek ücret

Hızlı yükselme

İş-yaşam dengesi

Esnek ve rahat bir çalışma ortamı

Profesyonel gelişimlerine destek olunması

Anlık geribildirim, Yoğun ilgi

Rehberlik, Mentorluk, Koçluk

Anında ödül, takdir ve teșekkür

Aktif katılma, örgüt içerisinde söz sahibi olma ve sorumluluk üstlenme

Sosyal ve eğlenceli bir çalışma ortamı

Emir komuta zincirinden hoşlanmazlar

Topluma sosyal katkı sağlayabilecekleri işler

Yöneticilerinden, yaratıcı ve yenilikçi fikirlere açık olmalarını; adaletli ve etik olmalarını ve kendilerini dinlemelerini beklerler.

\subsection{Y Kuşağının Örgütlerinden ve Yöneticilerinden Beklentileri}

Uluslararası çapta yapılan birçok önemli araștırma, Y Kuşağının örgütlerine yönelik sadakat duygularının güçlü olmadığını ve beklentilerinin karşılanmadığı durumlarda rahatlıkla başka kurumlara geçebildiklerini ortaya koymaktadır. Örneğin Deloitte'un,
Türkiye de dahil olmak üzere, 36 ülkeden toplam 10.445 katılımcıyla gerçekleştirdiği 2018 yılı araştırmasına göre, Y kuşağının \%43'ü iki yıl içerisinde çalıștıkları firmadan ayrılmak isterken; sadece \%28'i şu an çalıştıkları firmada 5 yıl ve üzerinde bir süre için kalmak istediklerini belirtmişlerdir. Türkiye'de ise bu oranlar sirasiyla $\% 50$ ve \%29'dur. Raporda, Y kuşağı çalışanlarını elde 
tutmanın anahtarı olarak onlara işyerinde daha fazla çeşitlilik sunmak, süreçlere daha fazla dahil etmek ve esneklik sağlamak gösterilmiştir (Deloitte Y Kuşağı Araştırması, 2018).

Görüldüğü gibi, iki yıl içinde çalıştıkları firmadan ayrılmayı düşünenlerin oranı oldukça yüksektir ve bu noktada, Y Kuşağını elde tutmak için neler yapılabileceğinin firma sahipleri ve yöneticiler tarafından titizlikle değerlendirilmesi gerekmektedir. Bu konuda, geçmişten günümüze yapılan birçok araștırmanın sonucu yol gösterici olabilir. Söz gelimi, PricewaterhouseCoopers şirketinin 2011 yılında 75 ülkeden 4364 kişinin katılımı ile gerçekleştirdiği Milenyum Kuşağ Araştırması'na göre bu kuşak için 'kişisel öğrenme ve gelişim fırsatları', işverenlerin çalışanlara sunduğu en önemli ek faydalarda birinci sırada; 'esnek çalışma saatlerinin olması' ise ikinci sıradadır. 'Ek ücret kazanımları' ise ancak üçüncü olabilmiştir. Aynı araştırmaya göre Y Kuşağının \%41'lik bir kesimi işlerini yüz yüze veya telefon yerine elektronik ortamda yapmayı tercih etmekte, \%75'i teknolojinin onları işte daha etkin yaptığını belirtmektedir (Özkan, 2017: 122).

Keleş (2011: 137) tarafından yapılan araştırmada ise Y Kuşağı çalışanlarının gerek görev tanımlarında gerekse çalışma koşullarında esneklik beklentisi içinde oldukları, sıkı denetime tabi olmalarının kendilerine güvenilmediği algısı yaratarak motivasyonlarını olumsuz etkilediği, işyerlerinde kendilerini rahat hissetmek istedikleri, çalıșma ortamı ve yönetim tarzının Y Kuşağı çalışanlarının motivasyonlarında önemli bir etki yarattığı tespit edilmiştir.

Great Place to Work Șirketi'nin Türkiye'de 2015 yllında İşletme, İktisat, Endüstri Mühendisliği, İnşaat Mühendisliği ve Matematik bölümlerinden öğrencilerle yaptığı araştırmada, Y Kuşağının kurum kültüründen beklentileri arasında en önemlisinin "dostça çalışma ortamı ve ekip ruhu" olduğu saptanmıştır. Ayrıca bu kuşağın, işyerindeki sonuçlarda kendi katkısını görmeyi, kendisini etkileyen kararlarda söz sahibi olabilmeyi, gurur duyduğu bir yerde çalışmayı ve şirket başarısının, kazancına adil bir şekilde yansımasını beklediği belirtilmektedir (Özkan, 2017: 117-118).

Y Kuşağı üyeleri, seçtikleri uğraşılarda başarılı olmalarına yardım etmek için onları yakından izleyen ve destekleyen ebeveynler ve öğretmenler ile büyümüş olduklarından kariyer kararları verirken de ebeveynlerine danışmaya veya güvendikleri daha deneyimli, bilgili rol modellerinin tavsiyelerine ihtiyaç duymaktadır (Ekiz, 2017: 29-30). Bu durumun, kendilerine ișyerinde bir baba/ağabey, anne/abla gibi yaklaşan paternalist bir yönetici tarzını tercih etmelerinin önemli bir nedeni olabileceği düşünülmektedir. $\mathrm{Bu}$ noktada paternalist liderlerinden kendilerine yol göstermesini, rehberlik, koçluk, mentorluk yapmasını bekleyebilirler.

Ekiz (2017: 29-30), Y kuşağının aradığg liderlik özelliklerini şöyle sıralamıştır:

- Görev odaklı liderlerin aksine insan odaklı liderler,

- $\quad$ Ekip çalışması, işbirliği ve destekleyici iletişim,

- Liderin astları ile arasındaki ilişkiye odaklanması,

- Astlarının bilgi birikimini ve kapasitesini anlamaya çalışması,

- Ulaşılabilir ve cana yakın olması,

- Çatışmalarda arabulucu olması,

- Motive etmesi ve cesaretlendirmesi,

- Güçlendirmesi ve akıl hocası olması,

- Kendisini çalışanlarına adaması,

- Astlarının savunucusu olması.

Y Kuşağının yöneticilerinden beklentilerini gösteren bu ifadelerin, Aycan'ın (2006) Paternalist Liderlik Ölçeğinde yer alan ifadelerle yakın benzerlik gösterdiği söylenebilir. Nitekim, bu çalışmada, Y Kuşağının etkili şekilde yönetilmesinde 
Paternalist Liderlik tarzının önemli bir araç olabileceği ileri sürülmektedir. Literatürde doğrudan Y Kuşağının Paternalist Liderlik beklentisini araştıran çalışmalar pek fazla bulunmasa da iki olgu arasındaki ilişkiyi işaret eden sonuçlara rastlanabilmektedir. Așağıdaki başlıkta bu ilişkinin irdelenmesine çalıșlacaktır.

\subsection{Türkiye'de Y Kuşağı ve Paternalist Liderlik İlişkisi}

Günümüzde paternalizm, hem Doğu hem de Batı toplumları tarafindan iş ve toplumsal yaşama ait birtakım sorunlarla baş edebilmek için bir çözüm olarak görülmektedir (Erben ve Ötken, 2014: 106). Örneğin Köksal (2011: 104), paternalist lider için çalışan birçok kişinin, örgütlerini, daha yüksek ücret veya daha iyi imkanlar için terk etmeyeceklerini öne sürmüştür. Gelmez ve Akça Ertürk (2019: 62) tarafından, Ankara'da özel bir hastanede çalışan 268 Y kuşağı katılımcı ile yapılan bir başka güncel araştırmada, iş performansına etki eden en güçlü liderlik boyutunun paternalist liderlik olduğu saptanmıștır.

Paternalist liderlik tarzında, liderin otoriteyi ve statüyü koruması ve astlardan itaat beklemesinin, Y kuşağının doğasına ters düşeceği kabul edilebilir. Nitekim, otoriteye meydan okuyan, önce ailelerini sonra da patronlarını sorgulamaktan çekinmeyen Y kuşağının sadece biçimsel güçten kaynaklanan bir otoriteye sorgulamadan boyun eğmesini beklemek pek gerçekçi bir yaklaşım olmayacaktır. Bununla birlikte Y Kuşağı üyeleri, saygıyı bir zorunluluktan çok; hak ettiğini düşündüğü kişilere göstermektedirler (Toruntay, 2011:79-80). Bu bağlamda Y Kuşağının paternalist liderin biçimsel otoritesinden ziyade bilgi ve uzmanlık gücüne ve/veya kişilik özelliklerine olan saygısından dolayı, gönüllü olarak ona itaat etmekte bir sakınca görmemesi de mümkündür.

Gürcan (2018: v) tarafından yapılan araştırmada, Y Kuşağı çalışanların, Batılı kültürlerde bağımsız, bireyci, yenilikçi ve benzeri özellikler ile nitelendirilse de, Türkiye'de kültürün etkisinden dolayı bu kușağın üyelerinin paternalist bir lideri tercih etmeyi sürdürdükleri ortaya çıkmıştır. 19-38 yaş arası 574 katılımcı ile gerçekleştirilen araştırmada, liderin paternalist liderlik davranışlarının Y Kuşağı çalışanların duygusal bağlılığını yüzde 44 arttırdığı saptanmıştır. Buna göre, Türkiye'de Y Kuşağı çalışanların; işyerinde aile ortamı yaratan, çalışanlarının iş dışı yaşamlarına dahil olan ve konumunun getirdiği hiyerarşi ve otoriteyi belirginleștiren liderlerle çalıștıklarında örgütlerine duydukları duygusal bağlılığın arttığı ifade edilmiștir.

Sargut (2001: 234), Türk çalışanların yöneticilerinden beklentilerini şöyle özetlemektedir: "Ülkemizde çalışanların liderlerini ana babaları yerine koyduklart; onların ilgi ve bakımını bekledikleri gözlenmektedir. Bireyci toplumların aksine, liderlerin kayıtsiz davranmaları hoş görülmemektedir. Böylesi bir ortamda, kuşkusuz özel yaşamla işyaşamının birbiri içine girme olasilı̆̆ı vardır. Bu nedenlerle Türk toplumundaki ast-üst ilişkisini, Batı tipi liderlik kuramlarıyla çözümlemeye kalkmak sağlıklı sonuçlar vermeyecektir."

Aktaş ve Sargut (2011: 159), paternalist davranış beklentisi yüksek toplumlarda evde babanın koruyuculuğunda ve yol göstericiliğinde yetișen bireylerin, daha sonraki hayatlarında sosyal öğrenmenin bir sonucu olarak, aynı rolü işyerlerinde üstlerinden beklediklerini; yönlendirilmeye ve bireysel ilgiye daha fazla gereksinme duyduklarını belirtmişlerdir. Sonuç olarak, yöneticiliğin ve liderliğin bu tip toplumlarda çok daha önemli ve geliştirilmesi gereken bir olgu olduğunu ileri sürmüşlerdir.

\section{ARAȘTIRMA}

Bu çalışmanın temel varsayımı, Türk kültürü açısından bakıldığında, Y Kuşağının önceki kuşaklara kıyasla daha bireyci özellikler göstermesine karşıllk, yöneticilerinden Paternalist liderlik davranışları beklentilerinin yüksek olacağı yönündedir. $\mathrm{Bu}$ varsayım doğrultusunda bir Survey 
araştırması tasarlanmış ve hazırlanan soru formu aracılığı ile veriler toplanmıştır.

\section{1. Örneklem}

Araştırmanın örneklem çerçevesini, 20182019 eğitim-öğretim yılının bahar yarıyılında, İzmir ilindeki bir devlet üniversitesinin üçüncü ve dördüncü sınıflarında öğrenimlerine devam etmekte olan 1208 İşletme Bölümü öğrencisi oluşturmaktadır. Bu rakam, öğrenci ișleri bürosunda sisteme kayıtlı durumdaki öğrenci listesine ulașılarak elde edilmiştir. Bu öğrencilerin 522'si üçüncü ve 686'sı dördüncü sınıf öğrencisidir. Bartlett, Kotrlik ve Higgins'e göre (2001: 48) 1000 kişilik ana kitle $(\mathrm{N})$ için 0,95 güven aralığında, $\alpha=0.05$ örneklem hatası ile evreni temsil edebilecek örneklem büyüklüğü 278 olmalıdır. Yapılan hesaplamada, 1208 kişilik ana kitle için .05 hata payı ile gerekli örneklem büyüklügünün 292 olduğu saptanmıștır (www.surveysystems.com, 2019).

Veriler, 18 Nisan- 17 Mayıs 2019 tarihleri arasında, tesadüfi olarak belirlenen derslere araştırmacı tarafından katılarak ve soru formları öğrencilere elden dağıtılarak toplanmıştır. Bu bağlamda, İktisadi ve İdari Bilimler Fakültesi, İşletme Bölümü, üçüncü ve dördüncü sınıflarda okuyan, Örgün ve İkinci Öğretim toplam 291 öğrenciden analiz için uygun veri toplanmıştır.

Kolayda örnekleme yönteminin kullanıldığı araştırmanın sonuçlarının, ülkedeki Y kuşağına mensup üniversite öğrencilerine genellenebilirliği bulunmamaktadır. Bununla birlikte, Türkiye'nin üçüncü büyük ili olan İzmir'in köklü üniversitelerinden birinde öğrenim gören ve ülkenin farklı şehirlerinden gelen bu öğrencilerin, $Y$ kuşağının liderlik beklentileri hakkında genel bir fikir verebileceği düşünülmektedir.

\subsection{Veri Toplama Aracı}

Araştırmada Aycan (2006: 461; Aycan vd., 2016: 192-193) tarafından geliștirilen ve 21 ifadeden oluşan "Paternalist Liderlik Anketi PLA" $(\alpha=$.85) kullanılmıştır. Bu anket, çalışanlara yönelik hazırlanmış olup hem mevcut yöneticilerinin davranışlarını değerlendirmeyi hem de zihinlerindeki ideal liderin nasıl olması gerektiğine ilişkin değerlendirmeyi içermektedir.

Mevcut araştırma, henüz işgücüne katılmamış olan öğrenciler üzerinde yapıldı̆̆ından anketin sadece "ideal lider" ile ilgili düşünceleri ölçmesi hedeflenmiştir. $\mathrm{Bu}$ doğrultuda 5'li Likert ölçeği 1: Çok Önemsiz, 2: Önemsiz, 3: Kararsızım/Fikrim Yok, 4: Önemli ve 5: Çok Önemli şekline dönüştürülmüş ve ifadelerde de bu ölçeğe uyarlamaya yönelik değişiklikler yapılmıştır. Örneğin orijinal ölçekteki "Yöneticim, çalışanlarına karşı aileden biri gibi davranır" ifadesi bu çalıșmada "Çalışanlarına karşı aileden biri gibi davranması" biçiminde ifade edilmiştir. Buna göre katılımcılardan, bir liderin verilen ifadelerdeki gibi davranmasının kendileri için ne kadar önemli olduğunu seçeneklerinden birini işaretleyerek belirtmeleri istenmiştir. Yüksek puanlar, yüksek paternalist liderlik beklentisini ifade etmektedir.

Paternalist Liderlik Ölçeğinin yanı sıra soru formunda öğrencilerin yaşını, cinsiyetini ve sınıflarını öğrenmeyi amaçlayan üç demografik soru da yer almaktadır.

\subsection{Bulgular}

\subsubsection{Demografik Özellikler}

Katılımcı öğrencilerin \%38'i (111) üçüncü sinıf ve \%62'si (180) dördüncü sinıf öğrencisidir. Cinsiyete göre dağılımları incelendiğinde, \%53,3'ünün (155) kadın ve \%46,7'sinin (136) erkek öğrenci olduğu görülmektedir. 291 öğrencinin 261'i 21-24 yaş aralığındadır. Kalan öğrencilerin 7'si $(\% 2,4)$ 20 yaşında olup 28'i $(\% 9,6) 25$ ve üzeri yaştadır.

\subsubsection{Faktör Analizi}

İlk olarak ölçekteki 21 ifade faktör analizine tabi tutulmuştur. Kaiser-Meyer-Olkin (KMO) örneklem uygunluk ölçüsü 0,737 olarak tespit edilmiştir. Bartlett küresellik testine göre sonuçlar $\mathrm{p}=.000$ olduğundan faktör analizinin 
bu değişkenler için uygun olduğu görülmüştür.

Gerçekleştirilen faktör analizleri sonucunda 15. ifade olan 'Dış eleștirilere karşı çalışanlarını koruması' hiçbir boyuta dahil olmadığından analiz dişında bırakılmıştır. Tekrar gerçekleștirilen faktör analizlerinde ise 'Çalışanlarından sanki kendi çocuklarımmış gibi sorumlu hisseder' (5. ifade) ve 'Çalışanlarla ilișkilerinde neșe, üzüntü, öfke gibi duygusal tepkiler vermesi' (2. ifade) ifadeleri, iki faktöre dağıldığı için analiz dışında bırakılmıştır. Geri kalan 18 madde tekrar faktör analizine tabi tutulmuştur. Bu analize ilişkin sonuçlar Tablo 2 'de gösterilmektedir. KMO = .722 bulunduğundan faktör için değişkenler uyumludur. Bartlett testine göre sonuçlar $(929,886) \mathrm{p}=0,000$ düzeyinde anlamlıdır.

Tablo 2: Faktör Analizi Sonuçları

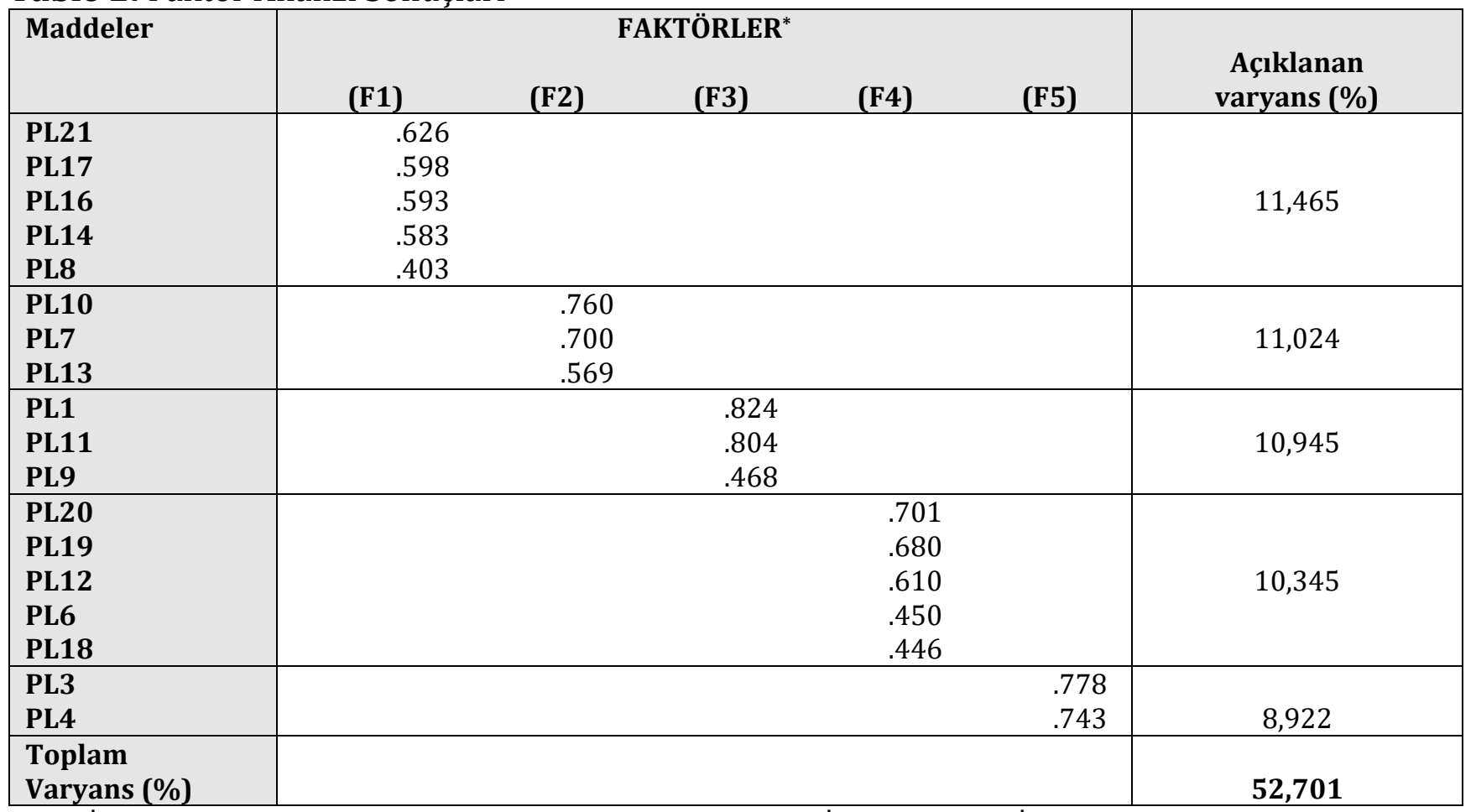

*(F1): İş dışındaki konularla ilgilenme, (F2): Bireyselleştirilmiş İlişkiler, (F3): İş yerinde Aile Ortamı, (F4): Statü Hiyerarşisi ve Otorite, (F5): Koruyucu Ebeveyn Davranışları

$\mathrm{Bu}$ aşamada, orijinal ölçekteki gibi beş boyut ortaya çıkmıştır. Beş boyutun toplam varyansı açıklama yüzdesi 52,701'dir. Bununla birlikte, bazı ifadelerin orijinal ölçekten farklı boyutlar altında toplandığı görülmüștür. En önemli farklılık ise mevcut çalışmada Aycan'ın (2006) Sadakat Beklentisi olarak adlandırdığı alt boyutun ortaya çlkmaması; bunun yerine 'Çalışanları için neyin iyi olduğunu bildiğine inanır' (PL3) ve 'Gerektiğinde çalıșanları adına adım atmaktan çekinmez' (PL4) ifadelerinden oluşan ve bu çalışmada "Koruyucu Ebeveyn Davranıșı" olarak adlandırılan yeni bir alt boyutun ortaya çıkmasıdır.

\subsubsection{Güvenilirlik Analizi}

Faktör analizi sonucunda 3 ifadenin ölçekten çıarılmasıyla kalan 18 ifade güvenilirlik analizine tabi tutulmuştur. Ölçeğin toplam güvenilirliği .72 olarak bulunmuştur. Herhangi bir ifade ölçekten çıkarıldığında ölçeğin Cronbach's Alpha değerinde önemli bir yükselme olmadığı görülmüş ve ölçeğe müdahale edilmemiştir.

Alt boyutların güvenilirlikleri incelendiğinde, iç tutarlılıkların yüksek olmadığı ancak kabul edilebilir düzeyde oldukları görülmüştür. Cronbach's alpha değerleri Tablo 3'te görüldüğü üzere 0.55 ile 0.66 arasında 


\section{E. TOLAY}

değerler almıştır. Buna göre Aile Ortamı yaratma boyutunun oldukça güvenilir $0.60 \leq$ $\alpha<0.80$ ); diğer alt boyutların ise güvenilir

$(0.40 \leq \alpha<0.60)$ olduğu söylenebilir (Özdamar,1999;522).

Tablo 3: Paternalist Liderlik Anketinin Güvenilirlik Analizi

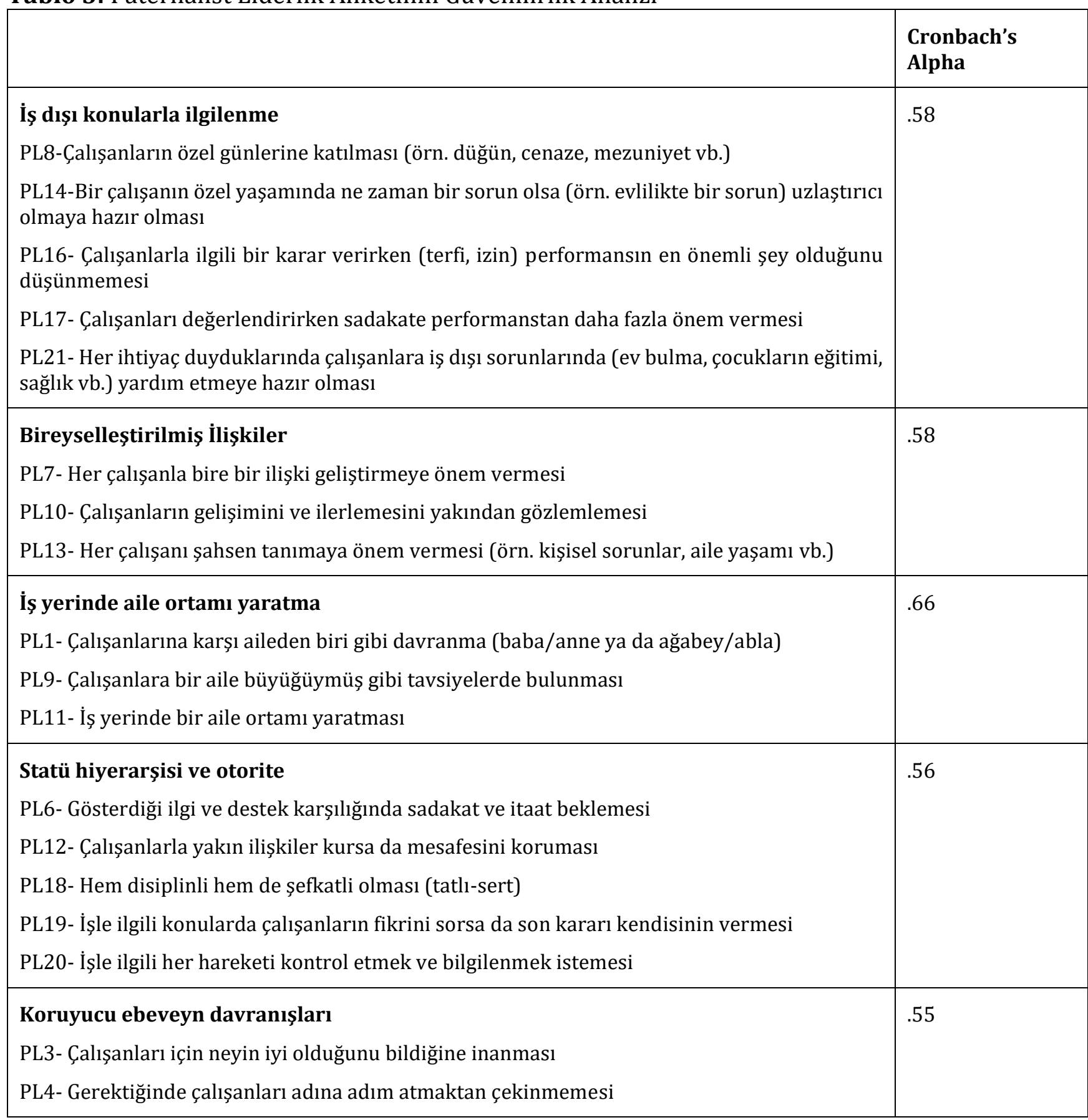

$(\mathrm{N}=291)$

\subsubsection{Tek Örneklem t Testi Analizi Bulguları}

Araştırmada, ortalama değerden farklılık olup olmadığını test etmek amacıyla Tek Örneklem t Testi yapılmıştır. Buna göre, boş hipotez için
“Paternalist liderlik boyutlarının ortalamasinın $(\mu)$, ana kitlenin ortalama değerinden $\left(\mu_{0}\right)$ küçük veya ona eşit olacağı" hipotezi test edilmiştir $\left(\mathrm{H}_{0}: \mu \leq \mu\right)$ (Özdemir, 2013: 257-258). $\mathrm{Bu}$ durumda $\mathrm{H}_{1}$ için 
"Paternalist liderlik boyutlarının ortalamasının $(\mu)$ ana kitlenin ortalamasından $(\mu 0)$ yüksek olacağı iddia edilmiştir. Bu çalışmada ana kitlenin ortalama değeri 3'tür ${ }^{2}\left(\mathrm{H}_{0}: \mu \leq 3 ; \mathrm{H}_{1}: \mu>3\right)$. Bu bağlamda, ölçekteki alt boyutlar için hipotezler aşağıldaki șekilde oluşturulmuştur:

H1: Y Kuşağı öğrencilerin ideal yöneticiden bekledikleri İș Dışındaki Konularla İlgilenme düzeyi, ortalamanın üzerinde olacaktır.

$\mathbf{H}_{2}$ : Y Kuşağı öğrencilerin ideal yöneticiden bekledikleri Bireyselleştirilmiş İlişki düzeyi, ortalamanın üzerinde olacaktır.

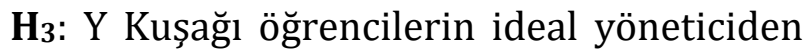
bekledikleri İș Yerinde Aile Ortamı Yaratma düzeyi, ortalamanın üzerinde olacaktır.

$\mathbf{H}_{4}$ : Y Kuşağı öğrencilerin ideal yöneticiden bekledikleri Statü Hiyerarşisi ve Otorite düzeyi, ortalamanın üzerinde olacaktır.
H5: Y Kuşağı öğrencilerin ideal yöneticiden bekledikleri Koruyucu Ebeveyn Davranışı düzeyi, ortalamanın üzerinde olacaktır.

Tablo 4'te, Paternalist Liderlik alt boyutlarının ortalama ve standart sapma değerleri incelenebilir. Buna göre, katılımclların ideal liderden en fazla Koruyucu Ebeveyn Davranışları bekledikleri söylenebilir $(\bar{x}=4.05)$. Bunu, Statü Hiyerarşisi ve Otorite $(\bar{x}=3,99)$ ile Bireyselleştirilmiş İlişkiler $(\bar{x}=3,99)$ izlemektedir.

İş Dışı Konularla İlgilenme düzeyinin ise test değeri olan 3'e çok yakın olduğu görülmektedir $(\bar{x}=3,06)$. Nitekim, Tablo 4'te bu alt boyutun ortalamasinda, istatistiksel açıdan anlamlı bir farklılık bulunmadığı görülmektedir. Bunun dışındaki tüm boyutların ortalamaları, test değeri olan 3'ten yüksek olup istatistiksel açıdan anlamlı bir farklıllk söz konusudur.

Tablo 4: Tek Örneklem Testi

\begin{tabular}{|c|c|c|c|c|c|c|c|c|c|}
\hline & \multicolumn{9}{|c|}{ Test Değeri = 3} \\
\hline & \multirow[t]{2}{*}{ Ortalama } & \multirow[t]{2}{*}{ St. Sapma } & \multirow[t]{2}{*}{$\begin{array}{l}\text { St. Hata } \\
\text { Ort. }\end{array}$} & \multirow[t]{2}{*}{$\mathbf{t}$} & \multirow[t]{2}{*}{ df } & \multirow{2}{*}{$\begin{array}{l}\text { Sig. } \\
\text { (2- } \\
\text { tailed) }\end{array}$} & \multirow[t]{2}{*}{$\begin{array}{l}\text { Anlam } \\
\text { Farkı }\end{array}$} & \multicolumn{2}{|c|}{$\begin{array}{c}\text { Farkın \%95 Güven } \\
\text { Aralığı }\end{array}$} \\
\hline & & & & & & & & Lower & Upper \\
\hline İŞ DIŞI & 3,06 & .70527 & .04134 & 1,496 & 290 & .136 & .06187 & -.0195 & .1432 \\
\hline BÍREYSEL & 3,99 & .68033 & .03988 & 24,889 & 290 & .000 & .99262 & .9141 & 1.0711 \\
\hline AIILE ORTAMI & 3,58 & .74166 & .04348 & 13,358 & 290 & .000 & .58076 & .4952 & .6663 \\
\hline OTORITE & 3,99 & .58114 & .03407 & 29,042 & 290 & .000 & .98935 & .9223 & 1.0564 \\
\hline KORUYUCU & 4,05 & .82174 & .04817 & 21,758 & 290 & .000 & 1.04811 & .9533 & 1.1429 \\
\hline
\end{tabular}

Sonuç olarak, $\mathrm{H} 1$ hipotezi reddedilirken $\mathrm{H} 2$, H3, H4 ve H5 hipotezleri kabul edilmiștir. Buna göre, araştırmaya katılan Y Kuşağı öğrencilerin, zihinlerindeki ideal liderden, kendileri ile Bireyselleştirilmiş ilişkiler kurma, İş yerinde aile ortamı yaratma, Statü Hiyerarşisi ve Otoriteyi koruma ve Koruyucu Ebeveyn Davranışları sergilemeye yönelik beklentilerinin, çalışmada iddia edildiği gibi, yüksek olduğu saptanmıştır.

\section{SONUÇ VE TARTIŞMA}

Paternalizm liderlik, Bireyci Batı kültürlerinde arzulanmayan ve hatta yadırganan bir liderlik tarzıdır. $\mathrm{Bu}$ yönüyle, paternalist liderliğin

2 Çalışmada 1= Çok Önemsiz - 5: Çok Önemli olmak üzere 5'li Likert Ölçeği kullanılmış olup hipotezlerdeki evrensel bir karakteristik taşımadığı çok açıktır. Bu liderlik türünün, Türkiye'nin de aralarında bulunduğu Uzak Doğu, Orta Doğu ve Güney Amerika gibi geleneklerine ve aileye bağll, toplulukçu kültürlere daha uygun olduğu bilinmektedir. Buna karşılık, yine tüm dünyada olduğu gibi Türkiye'de de Y Kuşağının, önceki kuşaklara kıyasla, daha bireyci, bağımsızlığına düşkün, otoriteyi sorgulayan ve kolayca boyun eğmeyen tutumlara sahip olduğu bilinmektedir. $\mathrm{Bu}$ açıdan bakıldığında, Y Kuşağının yöneticilerinden paternalist liderlik beklentilerinin düşük olacağı söylenebilir.

"ortalama değer", 3=Kararsızım/Fikrim Yok seçeneğini ifade etmektedir. 
Ancak, madalyonun öteki yüzü farklıdır. Y Kuşağı, 'helikopter aileler' olarak nitelendirilen, çocuklarının her sorunu ile yakından ilgilenen; bu sorunları hızla ele alıp çözüm getirebilen ebeveynlerle büyüdüklerinden, sosyal öğrenmenin sonucu olarak, iş yaşamına atıldıklarında yöneticilerinden de böyle 'özel' bir ilgiyi talep edebilmektedir. Nitekim araştırmalar, Y Kuşağının yöneticilerinden anlık geribildirim vermesini, mesleki gelişimi ile yakından ilgilenmesini, mentorluk yapmasını, esnek ve rahat bir çalışma ortamı yaratmasını, ilişki odaklı bir yaklaşım sergilemesini beklediklerini ve bu beklentileri karşılandığında memnuniyet düzeylerinin arttığını göstermektedir (Keleş, 2011; Toruntay, 2011; Yüksekbilgili, 2013; Kuru, 2014; Wiedmer, 2015; Göktaș, 2016; Ekiz, 2017; Özkan, 2017 vb.). Bunun da ötesinde, rahatlıkla iş değiştirebilen yapıları ile karakterize edilen Y Kuşağını, bu beklentileri karşılanmadığında örgütte tutmanın çok da mümkün olamayacağı ifade edilmektedir. $\mathrm{Bu}$ bağlamda günümüzde gerek Doğu gerekse Batı toplumlarında, paternalizmin Y Kuşağını yönetmede karşılaşılan birtakım sorunların çözümünde faydalı olabileceği dile getirilmeye başlanmıştır (Örneğin, Erben ve Ötken, 2014)

Türkiye özelinde konuya yaklaşıldığında ise Türk Y Kuşağının, ulusal kültürün etkisiyle, batıdaki akranlarından farklı özelliklere sahip olduğunu tespit eden araştırma sonuçları bulunmaktadır (Örneğin Yüksekbilgili, 2013: 353). Bu bilgilerden hareketle bu çalışmada Türkiye'deki Y Kuşağının Paternalist Liderlik beklentilerinin yüksek olacağı ileri sürülmüş ve analiz sonuçları bu varsayımları desteklemiştir.

$\mathrm{Bu}$ çalışmada, İzmir ilindeki bir üniversitede öğrenim gören Y Kuşağına mensup İşletme Bölümü öğrencilerinin liderlik beklentileri, Paternalizm boyutu açısından değerlendirilmiştir. Elde edilen sonuçlar, araştırmanın beş hipotezinden dördünü desteklemiştir. Buna göre, katılımcıların ideal bir liderden bekledikleri Bireyselleștirilmiş ilişki, İş yerinde aile ortamı yaratma, Konum hiyerarşisi ve otorite ile Koruyucu Ebeveyn Davranışı düzeyleri, ortalama değer olan 3'ten yüksek çıkmıştır. Bir başka ifadeyle, Y Kuşağı öğrenciler gelecekteki yöneticilerinden paternalist bir liderlik tarzı beklemektedirler. $\mathrm{Bu}$ sonuç, Türk kültürü ile uyumlu olup geçmişte yapılan araştırma sonuçları ile de paraleldir (örneğin, Aycan ve Kanungo, 2000; Sargut, 2001; Erkuş vd., 2010; Schroeder, 2011; Aktaş ve Sargut, 2011 vb.).

Literatürde, Y Kuşağının, bireyci, bağımsız ve otoriteyi sorgulayan özellikleri nedeniyle Paternalist bir lider ile uyumlu çalışamayacakları vurgulanmaktadır. Bununla birlikte ulusal kültürün etkisiyle Türkiye'deki Y Kuşağının bazı konularda dünyadaki akranlarından farklılı gösterdiği belirtilmektedir. Bu araştırmanın sonuçları, bu bilgiyi desteklemiştir. Buna göre, Türkiye'de yöneticiler, Batılı tarzda bir yönetici profili sergilemek zorunda değildir. Paternalist bir liderle çalışmayı isteyen Y Kuşağını yönetirken, onlar için iyi olduğunu düşündüğü kararları onların adına alabilir, işyerinde aile benzeri bir çalışma ortamı yaratabilir, astlarına birey olarak yakın davranabilir, onların kişisel ve mesleki gelişmelerine destek olacak faaliyetlerde bulunabilirler. Araştırmada sadece 'İş dışı alanlara dahil olma' boyutu ile ilgili hipotez desteklenmemiştir. $\quad \mathrm{Bu}$ bakımdan yöneticilerin, astlarının 'özel yaşama müdahale’ olarak algılayabilecekleri durumlar hakkında dikkatli davranmaları önerilebilir.

$\mathrm{Bu}$ araştırma, daha önce de belirtildiği üzere, bir ön çalışma olarak tasarlanmıştır. Bundan sonraki aşamada, aktif olarak iş yaşamında yer alan ast ve üst konumundaki Y Kuşağı bireyler ile araştırma yapılması planlanmaktadır. Aycan tarafından geliştirilen PLA aracının güvenilirliğini ve geçerliliğini de test etme amacı taşıyan mevcut çalışmada, bu ölçme aracının genel güvenilirliği orta düzeyde (.72) olmakla birlikte alt boyutların güvenilirliklerinin orta ve düşük seviyelerde olduğu görülmüştür. $\mathrm{Bu}$ açıdan ölçeğin 
geliștirilmesi ve/veya Türk kültürüne daha uygun bir başka ölçme aracının kullanılması gerektiği düşünülmektedir.

$\mathrm{Bu}$ çalışma, İzmir ilindeki bir devlet üniversitesinde öğrenim gören öğrencilerin zihinlerindeki "ideal yönetici" davranışlarını araştırmıștır. Daha geçerli ve genellenebilirliği yüksek sonuçlar elde edebilmek için, konuya ilgi duyan araștırmacılara, iș yaşamında aktif olarak yer alan, daha çeşitli ve geniş sayıda örneklemler ile araştırmalar yapmaları önerilebilir. Bu araştırmalardan elde edilecek bilgilerin, konuyla ilgili literatürü zenginleștirmesinin yanı sıra iş yaşamındaki kuşaklararası farklılıklardan kaynaklanan çatışmaların çözümünde yardımcı olabileceği düşünülmektedir.

\section{REFERANSLAR}

AKTAŞ, M. ve SARGUT, A. S. (2011). “İzleyicilerin Kültürel Değerlerine Göre Liderliğe Duyulan Gereksinme Nasıl Farklılaşır?: Kuramsal Bir Çerçeve”, Amme İdaresi Dergisi, 44(4): 145-163.

AYCAN, Z. ve KANUNGO, R. N. (2000). “Toplumsal Kültürün Kurumsal Kültür ve İnsan Kaynakları Uygulamaları Üzerine Etkileri". Z. Aycan (Ed.), Türkiye'de Yönetim, Liderlik ve Insan Kaynakları Uygulamaları. Ankara: Türk Psikologlar Derneği Yayınları, 25-53.

AYCAN, Z. (2001). "Paternalizm: Özgün Yönetim ve Liderlik Anlayışına İlişkin Üç Görgül Çalışma". Yönetim Araştırmaları Dergisi. 1(1): 11-31.

AYCAN, Z. (2006). "Paternalism: Towards Conceptual Refinement and Operationalization". (Eds. U. Kim, K. S. Yang \& K. K. Hwang). Indigenous and Cultural Psychology: Understanding People in Context. New York, NY: Springer: 445-466.

AYCAN, Z.; KANUNGO, R. N. ve MENDONÇA, M. (2016). Kültürler Arası Bağlamda Örgütler ve Yönetim. Koç Üniversitesi Yayını. İstanbul.

BARTLETT, J. E., KOTRLIK, J. W. ve HIGGINS, C. C. (2001). "Organizational Research: Determining Appropriate Sample in Survey Research". Information Technology, Learning and Performance Journal. 19(1): 4350.
BAYRAMOĞLU, G. (2018). "X ve $Y$ Kuşağının Liderlik Açısından Karşılaștırılması". Ege Akademik Bakış Dergisi. 18(1):15-30.

CERIT, Y. (2012). "Paternalistik Liderlik ile Yöneticiden ve İșin Doğasından Doyum Arasındaki İlişki". Ondokuz Mayıs Üniversitesi Eğitim Fakültesi Dergisi, 31(2): 35-56.

ÇEVIK TEKIN, İ. ve AKGEMCİ, T. (2016). "Y Kuşağı Çalışanların İş Değerlerinin Araştırılması: Konya İli Sanayi İşletmelerinde Bir Uygulama”. Örgütsel Davranış Araştırmaları Dergisi. 1(2): 15-52

Deloitte Y Kuşağı Araştırması (2018), https://www2.deloitte.com/tr/tr/pages/abo ut-deloitte/articles/deloitte-y-kusagiarastirmasi-2018.html, Erişim Tarihi: 29.09.2019

EKiZ, S. (2017). Kamu Kurumlarında $Y$ Kuşağının Liderlik Beklentilerine Etki Eden Demografik Faktörler Üzerine Bir Çalışma: Adana Büyükșehir Belediyesi Örneği. Çă̆ Üniversitesi SBE, Yüksek Lisans Tezi. Mersin.

ERBEN, G. S. (2004). “Toplumsal Kültür Aile Kültürü Etkileşimi Bağlamında Paternalizm Boyutuyla İşletme Kültürü: Türkiye Örneği". 1. Aile İşletmeleri Kongresi, İstanbul Kültür Üniversitesi: İstanbul. s. 345356.

ERBEN, G. S. ve ÖTKEN, A. B. (2014). "Paternalistik Liderlik ve İșe İlişkin İyilik İlişkisinde İş-Yaşam Dengesinin Rolü". 
Yönetim ve Ekonomi Araştırmaları Dergisi. 22: 103-121.

ERDEM OKUMUŞ, B. (2016). Kuşak Farkı Özelliklerine Göre Sekillenen Ofis İç Mekan Tasarımı Kriterlerinin Irdelenmesi - $Y$ ve $Z$ Kuşağı Üzerine Araștırma ve Model Önerisi. Mimar Sinan Güzel Sanatlar Üniversitesi, Fen Bilimleri Enstitüsü, Doktora Tezi, İstanbul.

ERKUŞ, A., TABAK, A., YAMAN, T. (2010). "Paternalist (Babacan) Liderlik Çalışanların Örgütsel Özdeșleşmelerini ve İşten Ayrılma Niyetlerini Etkiler mi? Bir Özel Hastane Uygulaması". 9. Ulusal İşletmecilik Kongresi, 68 Mayıs 2010, Zonguldak. s. 594-597.

GELMEZ, M. ve AKÇA ÜRTÜRK, E. (2019). "Özel Bir Hastanede Liderlik Stillerinin ve Çalışan Performansının İncelenmesine Yönelik Bir Araştırma". Hacettepe Sağlık Ídaresi Dergisi, 22(1): 51-72.

GÖKTAŞ, P. (2016). "Y Kuşağının İletişim Sorunlarının Analizi ve Çözüm Önerileri: Süleyman Demirel Üniversitesi MYO Örneği". Karadeniz Teknik Üniversitesi İletişim Fakültesi Elektronik Dergisi. 3(11): 32-50.

GÖKTAŞ, P. ve ÇARIKÇI, İ. H. (2016). "Siyasi Liderlerden Beklenen Liderlik ve İletişim Tarzları: Y Kuşağı Üzerine Bir Araștırma". Ankara Üniversitesi SBF Dergisi. 71(3): 855-888.

GÜRCAN, N. (2018). Türk Kültüründe Paternalist Liderlik Davranışlarının İzleyenler Üzerindeki Etkisi: Y Kușağına Yönelik Bir Araștırma. DEÜ SBE Yüksek Lisans Tezi, İzmir.

KABASAKAL, H. ve BODUR, M. (2008). "Leadership and Culture in Turkey: A Multifaceted Phenomenon". 835-874. Culture and Leadership Across the World. The GLOBE Book of In-Depth Studies of 25 Societies. Edited by: Jagdeeo S. Chhokar, Felix C. Brodbeck, Robert J. House. Lawrence Erlbaum Associates, Publishers, New Jersey.

KELEŞ, H. N. (2011). "Y Kuşağ Çalışanlarının Motivasyon Profillerinin Belirlenmesine Yönelik Bir Araştırma”.
Organizasyon ve Yönetim Bilimleri Dergisi. 3(2): 129-139.

KÖKSAL, O. (2011). "Bir Kültürel Liderlik Paradoksu: Paternalizm”. Mustafa Kemal Üniversitesi Sosyal Bilimler Enstitüsü Dergisi, 8(15): 101-122.

KURU, İ. (2014). Y Kuşağı ve İş Yaşam Dengesi. Bahçeşehir Üniversitesi, SBE, İKY Yüksek Lisans Tezi, İstanbul.

METE, Y. A. ve SERIN, H. (2015). "Okul Yöneticilerinin Babacan Liderlik Davranışı ile Öğretmenlerin Örgütsel Vatandaşlık ve Örgütsel Sinizm Davranışları Arasındaki İlişki”. Hasan Ali Yücel Eğitim Fakültesi Dergisi, 12-2(24): 147-159.

ÖZDAMAR, K. 1999). Paket Programlar ile Ístatistiksel Veri Analizi-1. Kaan Kitabevi: Eskişehir.

ÖZDEMIR, A. (2013). Yönetim Biliminde İleri Araştırma Yöntemleri ve Uygulamalar. Beta Basım A.Ş., İstanbul.

ÖZKAN, G. (2017). Küresel Eğilimler Doğrultusunda İşin Geleceği: Y Kuşağının Beklentileri ve Kamu İstihdam Kurumlarının Rolü. Çalışma ve Sosyal Güvenlik Bakanlığı, Türkiye İş Kurumu Genel Müdürlügü, Uzmanlık Tezi, Ankara.

PELLEGRINI, E. K. (2006). A CrossCultural Investigation of the Relations Among Organizational Justice, Paternalism, Delegation and Leader-Member Exchange (LMX) Relationships. A dissertation of Doctor of Philosophy, University of Miami, Florida.

SIMPLE SIZE CALCULATOR. https://www.surveysystem.com/sscalc.htm, Erişim Tarihi: 12.07.2019.

SARGUT, A. S. (2001). Kültürler Arası Farklılaşma ve Yönetim. İmge Kitabevi, Ankara.

SCHROEDER, J. L. (2011). The Impact of Paternalism and Organizational Collectivism in Multinational and Family-owned Firms in Turkey. A Thesis of Master of Arts, Department in Psychology, University of South Florida. 
İzmir İktisat Dergisi (İzmir Journal of Economics) , Yll:2020, Cilt:35, Sayı:1, ss. 123-139

ŞENDOĞDU, A. A. ve ERDİRENÇELEBİ, M. (2014). "Paternalist Liderlik ile Örgütsel Vatandaşlık Davranışı Arasındaki İlişkiye Yönelik Bir Araştırma”. Selçuk Üniversitesi İktisadi ve İdari Bilimler Fakültesi, Sosyal ve Ekonomik Araştırmalar Dergisi, 14(27): 253274.

TORUNTAY, H. (2011). Takım Rolleri Çalışması: $X$ ve $Y$ Kuşağı Üzerinde
Karșılaștırmalı Bir Araștırma. İstanbul Üniversitesi, SBE, Yüksek Lisans Tezi, İstanbul.

WIEDMER, T. (2015). "Generations Do Differ: Best Practices in Leading Traditionalists, Boomers, and Generations X, Y. And Z". Delta Kappa Gamma Bulletin, 82(1):51-58.

YÜKSEKBILLGILİ, Z. (2013). “Türk Tipi Y Kuşağı". Elektronik Sosyal Bilimler Dergisi. 12(45): 342-353. 